\title{
ARTIGOS
}

\section{PEDAGOGIA DA VIGILÂNCIA: O JESUITTA NA ALDEIA (SÉCULOS XVI E XVII)}

MARCOS ROBERTO DE FARIA

\section{RESUMO}

Aprofundar a discussão acerca da prática jesuítica na província do Brasil no final do século XVI e início do XVII é a preocupação primeira deste artigo. Nesse caminho, resgatam-se alguns apontamentos a respeito dos instrumentos de vigilância que a chamada Contrarreforma pôs em cena, a fim de oferecer ao leitor as condicionantes históricas que perpassaram a atividade dos inacianos no período. Em seguida, faz-se uso de documentos pesquisados no Archivum Romanum Societatis Iesu e na Biblioteca Nazionale Centrale Vittorio Emanuelle, ambos em Roma. Por meio dessa documentação, tem-se a intenção de instigar o leitor a uma nova perspectiva em relação à atuação dos jesuítas na América portuguesa, fundamentalmente porque a fonte de que se faz uso neste artigo ainda foi pouco explorada.

HISTÓRIA DA EDUCAÇÃO • PEDAGOGIA • JESUÍTAS • BRASIL

\section{THE PEDAGOGY OF VIGILANCE: JESUITS IN THE VILLAGE (XVI AND XVII CENTURIES)}

\section{ABSTRACT}

This article aims primarily to discuss the Jesuit practice in Brazil in the late XVI and early XVII centuries. To this end, we employ the surveillance tools used by what was known as the Counter-Reformation to present the historical conditions that permeated the Ignatians' activities at the time. A new perspective on the role played by the Jesuits in Brazil is then presented based on documents researched at the Archivum Romanum Societatis Iesu and the Biblioteca Nazionale Centrale Vittorio Emanuelle, both in Rome, sources which have been rarely used so far. 


\section{PÉDAGOGIE DE LA VIGILANCE: PRÉSENCE JÉSUITE DANS LES VILLAGES (XVI ET XVII SIĖCLES)}

RÉSUMÉ

Cet article vise principalement à approfondir la discussion sur les pratiques des jésuites dans la province du Brésil à la fin du XVI et au début du XVII siècle. Le travail dans cette voie reprend d'abord des notes concernant les instruments de vigilance mis em place par le mouvement dit de la Contre-Réforme, afin d'éclairer le lecteur sur les conditions historiques qui façonnèrent l'activité des ignaciens pendant cette période. Il utilize ensuite certains documents appartenant aux collections de l'Archivum Romanum Societatis Iesu et de la Biblioteca Nazionale Centrale Vittorio Emanuelle, toutes deux situés à Rome. Les sources utilisées dans cet article étant encore peu exploitées, par le biais de cette documentation, on entend inciter le lecteur à adopter une nouvelle perspective sur les activités des Jésuites em Amérique portugaise.

HISTOIRE DE L'ÉDUCATION • PÉDAGOGIE • JÉSUITES • BRÉSIL

RESUMEN

Profundizar la discusión acerca de la práctica jesuítica en la provincia de Brasil a fines del siglo XVI e inicio del XVII es la primera preocupación de este artículo. En este sendero, se rescatan algunos apuntes con respecto a los instrumentos de vigilancia, que la llamada Contrarreforma puso en escena, para ofrecer al lector los condicionantes históricos que permearon la actividad de los ignacianos en dicho período. A continuación, se hace uso de documentos investigados en el Archivum Romanum Societatis Iesu y en la Biblioteca Nazionale Centrale Vittorio Emanuelle, ambos en Roma. A través de esa documentación se tiene la intención de instigar al lector a una nueva perspectiva en relación a la actuación de los jesuitas en la América portuguesa, fundamentalmente porque la fuente utilizada en este artículo ha sido aún poco explorada. 


\section{SOBRE A "TECNOLOGIA CATÓLICA DE CONTROLE DO CORPO" NOS SÉCULOS XVI E XVII}

RECORTE CRONOLÓGICO DESTE ARTIGO É DETERMINADO PELA PRESENÇA DE VÁRIOS instrumentos de "ordenação" usados pela Igreja Católica para "colocar tudo em ordem". ${ }^{2}$ Dentre esses instrumentos estava o fortalecimento da "vigilância" que a Igreja contrarreformista evidenciou por meio das ordens religiosas do período, dentre as quais os jesuítas são a principal expressão. Penso que tratar dessa vigilância que a Igreja Católica pôs em cena é fundamental para trazer ao leitor a crise que se instalou na relação entre religião, poder e relações sociais nos séculos XVI e XVII. Por isso, neste artigo, discuto algumas questões que, avalio, são importantes para se conhecerem as ordenações dispostas pela "pedagogia da vigi-

Expressão tomada de Hansen (2004, p. 25)

Para Hansen, "ordem" é um conceito teológico-político que regula virtude e vício (2004, p. 26). É nesse sentido que deve ser tomado aqui.

Agradeço à Coordenação de Aperfeiçoamento de Pessoa de Nível Superior - Capes - pela bolsa sanduíche em Roma, que tornou possível o acesso a documentos e textos indispensáveis para essa pesquisa. lância” católica nesse período. Assim, procuro destacar, inicialmente, alguns tópicos gerais a respeito do controle da religião sobre o corpo. Enxergo nesse tema uma possibilidade de trazer ao leitor uma ideia a respeito dos modos usados pela Igreja contrarreformista para "vigiar" e "disciplinar" o indivíduo e suas relações sociais. Em seguida, trabalho com a documentação muito pouco explorada, pesquisada no Archivum Romanum Societatis Iesu - ARSI - e na Biblioteca Nazionale Centrale Vittorio Emanuelle - BNCVE -, ambos em Roma. ${ }^{3}$ Trata-se de documentação importante para verificar a tese do acirramento da ortodoxia e da pedagogia da vigilância acenadas neste artigo. 
Nessa direção, cabe perguntar: como se davam a vigilância e o controle sobre a "vida privada" e a sociabilidade nos séculos XVI e XVII? Referindo-se a esse período, Vigarello (2008) afirma que havia intenso trabalho da modernidade sobre as fronteiras do si mesmo, sobre as pulsões e os desejos: controle da polidez e da sociabilidade, polimento das violências, autovigilância dos gestos no universo do íntimo. A compostura cotidiana, as maneiras, a sexualidade, os jogos, o espaço próximo, tudo isso se transformou (VIGARELLO, 2008).

Gélis (2008) concordou com essa tese, destacando o papel da Igreja da Contrarreforma, que, segundo ele, reforçou a desconfiança que o magistério já havia manifestado nos séculos medievais a respeito do corpo, “esta abominável veste da alma”. Corpo depreciado do ser humano pecador, pois se ouvia incessantemente dizer que era pelo corpo que ele corria o risco de perder-se. O pecado e o medo, o medo do corpo, principalmente o medo do corpo da mulher, retornaram como uma ladainha sob forma de precauções ou de condenações (GÉLIS, 2008).

Sabe-se, de acordo com Gélis (2008), que o Corpo de Cristo está no centro da mensagem cristã e o cristianismo é a única religião na qual Deus se inscreveu na história tomando forma humana: a religião do Deus encarnado (GÉLIS, 2008). Discutindo essa questão, Certeau (1987) afirmou que a pergunta “o que é o corpo?” atormenta o discurso místico desde o fim da Idade Média. De acordo com o autor, o cristianismo foi instituído sob a "perda de um corpo, o corpo de Jesus". E a pergunta feita por Maria Madalena diante do túmulo vazio - “onde o colocaram?” - organizava o discurso apostólico de modo que os que criam continuavam perguntando: “onde estás?” - e, de século em século, perguntavam à história que passava: “onde o colocaram?” (CERTEAU, 1987).

Para Certeau (1987), nos séculos XVI e XVII, a oposição entre o corpo "político" e o corpo "místico" da Igreja, já perceptível ao fim da Idade Média, reforçou-se. A oposição atravessou também os ambientes católicos, marcados pela apologética antiprotestante - que ora privilegiava o caráter externo e visível da Igreja, ora procurava no "espiritualismo" um contraponto à politização do Estado ou do mundo. Assim, no século XVII, a "venerável palavra” contemplativi ou spirituali aparece sempre em numerosos títulos:

\footnotetext{
Jardim des Contemplatifs (1605), Philosophie des Contemplatifs (1618), De contemplatione divina (1620), Vie della contemplazione (1626), Tratado de vida contemplativa (1627), Sospiri profundi dell'anima contemplativa (1651), Les Contemplations (1654), Tractatus brevis de vita contemplativa (1663), ecc. (CERTEAU, 1987, p. 142)
} 
A persistência do "espiritual”, que reportava a São Paulo, era, então, ainda mais fortemente manifesta (CERTEAU, 1987).

Como consequência dessa "persistência do espiritual”, é possível dizer, juntamente com Gélis (2008), que, para todos aqueles que procuravam assemelhar-se ao Cristo, o corpo era, ao mesmo tempo, o maior obstáculo, o maior inimigo e o meio de acompanhar o Redentor: "o corpo que é preciso vencer”. Clamava Inácio de Loyola:

\section{Eu não sou mais do que um estrume; devo pedir a Nosso Senhor que na minha morte meu corpo seja jogado no lixão para que seja devorado pelas aves e cães. [...] Não é isso que devo desejar como castigo dos meus pecados?}

A imagem, tão espalhada no século XVII, do "homem de bem, Jó”, coberto de chagas infectas e fedorentas, humilhado em seu monturo, traduz bem tudo o que esse "saco de imundícies", que era o corpo, podia inspirar aos místicos. Uma atitude como essa em relação ao corpo ia de par com a condenação das doçuras e prazeres da vida. Aliás, essa atitude não era outra coisa senão uma morte camuflada. A morte já estava na vida (GÉLIS, 2008).

O corpo deveria, portanto, ser constantemente vigiado e disciplinado.

Dormir no chão duro da cela, "como verdadeiro penitente", vestir uma roupa de tecido grosseiro, rugosa e remendada, acrescentar a ela um ou dois cilícios que corroem a carne, levantar-se de noite para aplicar-se a disciplina com chibata ou com açoite são vias ordinárias pelas quais eles pretendiam superar os desvios do corpo. (GÉLIS, 2008, p. 60-61)

Essas práticas estavam, por assim dizer, bastante próximas ao que Inácio aplicava ao seu próprio corpo e ao que se praticaria nas casas jesuíticas que doravante iriam se espalhar pelo mundo nesse período.

Para castigar o corpo que ardia, extinguir o fogo da concupiscência, vencer a carne que se abrasava, muitas vezes não havia outro recurso senão a imersão na água fria; só ela podia extinguir o incêndio que ameaçava destruir a pessoa. Por ocasião de sua estada em Paris, em meados do século XVI, Inácio de Loyola mergulhou em uma água gelada com a intenção de mortificar não a sua própria carne, mas a de um devasso com o qual havia cruzado no caminho. E proclamou em alto e bom som que ficaria lá até que esse pecador impenitente renunciasse à sua paixão criminosa (GÉLIS, 2008).

Para Gélis (2008), tudo na conduta do santo deveria, pois, levar a imitatio Christi: cada intenção, cada comportamento, tudo era calcado 
em um episódio da morte redentora do Filho de Deus. Assim, Rita de Cássia definiu em sua cela sete lugares que correspondiam às sete grandes etapas da Paixão para reviver mais de perto o que Jesus viveu. Duas constantes eram perceptíveis nesses comportamentos vividos como o cumprimento extremo da escatologia da salvação. Primeiramente, a ideia de que estamos na Terra para sofrer e que é preciso fazer o sofrimento entrar na nossa "regra de vida". No entanto, esse sofrimento constantemente aguilhoado deveria igualmente trazer testemunho: ele não interessava, a não ser que se falasse dele, a não ser que outro qualquer falasse dele, seja durante a vida do santo, seja depois de sua morte. O martírio dos tempos modernos desenrolava-se sob o olhar do outro e, aqui, o papel desse outro era essencial, pois ele garantia a transmissão dos fatos e lhes dava sentido. Era essa relação que fazia o corpo martirizado do místico tornar-se “imagem sensível” do Corpo de Cristo (GÉLIS, 2008).

\begin{abstract}
Tomando sua parte nos sofrimentos de Cristo, encarnando assim o corpo sofredor da Igreja, os santos pensam menos em sua própria salvação do que na salvação dos outros. É pelos outros que eles aceitam o inaceitável e suportam o insuportável; e, imitando a Cristo, eles se veem por sua vez redentores. Esta encarnação da Igreja universal manifesta-se particularmente nos momentos de crise que a Instituição atravessa. (GÉLIS, 2008, p. 85)
\end{abstract}

Com esse espírito dos que "suportam o insuportável” e essas tentativas de ordenamento das práticas religiosas e de disciplina do corpo, os anseios religiosos do século XVI conviveram com o reforço da Devotio moderna ${ }^{4}$ que se encontrava dentro de um amplo movimento de "Reforma” entre o final da Idade Média e o início da Idade Moderna. Esse movimento impulsionaria o surgimento de novas ordens e congregações (como os jesuítas). A Devotio pode ser encarada como reação ao pessimismo que acompanhou o século XIV (Peste Negra e Cisma do Ocidente). Com ênfase na espiritualidade prática, em uma liturgia sem fausto e na volta às fontes cristãs, a Devotio era o mais influente movimento espiritual na Igreja do final da Idade Média (KARNAL, 1998).

Os jesuítas, como não poderia deixar de ser, reproduziram os ideais de seu fundador. Tais ideais estavam, por assim dizer, em sintonia com a ambiência desse período. Neste artigo veremos que esse ideário atravessou o oceano e determinou as práticas nas aldeias dos índios da América portuguesa. Vejamos como isso se deu e como afetou a vida dos próprios inacianos e imprimiu o reforço da pedagogia da vigilância sobre os nativos. moderna' tem as raízes mais profundas na região flamenga, especialmente entre os chamados 'irmãos de vida comum', aprovados como congregação em 1395. Desse grupo saiu Tomás de Kempis, possivelmente o autor da obra básica dessa postura, Imitação de Cristo" (KARNAL, 1998, p. 46, nota). 


\section{É PRECISO VISITAR O BRASIL: ANÁLISE DE DUAS VISITAS À PROVÍNCIA (1583 E 1607)}

Em sintonia com o que já foi destacado - sobre as implicações da Contrarreforma em relação ao corpo -, é pertinente ressaltar como se deu a relação dos inacianos com as "tentações" que a aldeia representava para o padre. A fim de verificar como se deu a relação do jesuíta com as práticas no âmbito das aldeias, cabe conhecer parte da documentação que diz respeito à temática deste artigo, produzida a partir de duas visitas à província do Brasil ordenadas por Roma nesse período: uma em 1583 e outra em 1607. Vamos aos documentos, pois.

Durante o período no qual Padre José de Anchieta foi provincial, realizou-se a Segunda Visita à Província do Brasil. ${ }^{5}$ De acordo com Leite (1938-1949), desde 1574 se pedia novo visitador para o Brasil, e que fosse “pessoa de importância”. O indicado para tal empresa foi Pe. Cristóvão de Gouveia (1542-1622): mestre em artes, natural de Porto, entrou na Companhia no dia 10 de janeiro de 1556. Estudou em Coimbra e Évora e ocupou os cargos de mestre dos noviços e reitor do Colégio de Bragança, da Universidade de Évora e do Colégio de Santo Antão de Lisboa, além de vice-reitor de Coimbra (LEITE, VIII, 1938-1949).

Um dos documentos produzidos ao final da visita do padre Gouveia à província do Brasil foi o chamado "regimento das aldeias". $\mathrm{O}$ regimento era dividido em cinco grandes seções. Em primeiro lugar, previa regras para o conjunto dos jesuítas da província: 22 parágrafos Para lo general de la província, concernindo, por exemplo, aos horários, à formação, à correspondência. Depois o regimento enfocava regras particulares conforme os diferentes lugares onde se podiam encontrar os jesuítas da província: o colégio, as capitanias, a aldeia e as missões. Essa mistura entre os termos jesuíticos (colégios e missões) e os termos especificamente brasileiros (capitania e aldeia) é emblemática do procediA Primeira Visita à Província do Brasil ocorreu em 1566 e teve como visitador Pe. Inácio de Azevedo. Para conhecer as instruções passadas pelo geral da Companhia, Pe. Francisco de Borja, ao visitador conferir Monumenta Historica Societatis lesu MHSI (1960, p. 323-329) documentos citados seguir encontram-se no ARSI e na Biblioteca Nazionale Centrale Vittorio Emanuelle, ambos em Roma. Na transcrição de tais documentos, foram respeitados o idioma, a grafia, as abreviaturas e a pontuação dos originais de que me valho. mento que presidiu à elaboração desse regimento: adaptar o espírito da Companhia (CASTELNAU-L'ESTOILE, 2006).

O papel da visita de Gouveia era, também, o de unificar as práticas espirituais. Para ajudar o jesuíta a alcançar sua salvação, o regimento deveria ajudá-lo a não cair em pecado. Era preciso, portanto, limitar as oportunidades, especialmente evitando-se a solidão de qualquer jesuíta (CASTELNAU-L'ESTOILE, 2006).

Desenhava-se, então, pelo regimento, uma espécie de clausura imaginária constituída pelo olhar do companheiro sempre presente. Observe-se o excerto: ${ }^{6}$

Não se mande de ordinário ninguém fora da casa sem companheiro, sem licença especial do padre provincial, nem por fora se apartem um do outro por distância em que não se possam ver um ao outro, a não ser por uma grande necessidade, e quando retornarem 
à casa que prestem contas disso ao superior. (Para lo general de la Província, \$9, ARSI, Brasilia Epistolae - Bras. - 2, fl. 141, grifos meus)

O documento insistia na manutenção da disciplina religiosa e da devoção nesse "lugar de tentações" que era a aldeia. Veja-se:

Que os superiores façam todo o possível para que os nossos se conservem em toda a disciplina religiosa de nosso Instituto e que procurem aumentar nas aldeias os exercícios espirituais e a devoção. (Para las Aldeas, §4, ARSI, Bras. 2, fl. 146)

O pecado da carne era, contudo, a mais forte tentação aos missionários. Nesse sentido, o inimigo declarado era a mulher índia, encarnação daquele pecado. Aqui o olhar do outro era solicitado a fim de pôr em prática o que chamo de "pedagogia da vigilância”. Repare-se:

E na medida do possível que eles não falem na portaria nem na
igreja com mulheres detendo-se com elas sem que esteja presente
uma outra pessoa da casa ou de fora e que eles não saiam de casa
na aldeia sem companheiro, nem nelas fiquem sem ele, enquanto
for possível. (Para las Aldeas, §4, ARSI, Bras. 2, fl. 146, grifos meus)

De acordo com as prescrições do regimento de Gouveia, o corpo era passível de disciplina e merecia ser castigado; era ainda um corpo que não podia se aproximar do "corpo da índia" e que, conforme veremos em excertos seguintes, não podia "dançar" e fazer "bailes de noite", que não podia ficar sozinho e que, por fim, deveria ser enterrado de acordo com os princípios cristãos.

Gouveia determinava, ademais, que as índias não se aproximassem da casa dos inacianos à noite e, uma vez mais, solicitava a presença do outro:

\footnotetext{
Quando for de noite, fechem-se as portas da casa que dão para fora, e o Superior logo recolha as chaves e não se sirvam de índias para trazer água, nem consintam que venham de noite com esmolas à portaria, e, se vierem, não vá um só recebê-las. (Para las Aldeias, §5, ARSI, Bras. 2, fl. 146, grifos meus)
}

O momento da refeição também era de práticas piedosas. Assim, antes das mesmas, determinou Pe. Gouveia: “ao princípio da mesa leia-se sempre um capítulo de Gerson ou livro pio, e à noite, acabada a ceia, o Martirológio, em vulgar” (Para las Aldeias, §8, ARSI, Bras. 2, fl. 146).

O missionário era, por definição, aquele que se ocupava em buscar sua própria salvação na redenção de seu próximo. No caso da aldeia, 
esse próximo era o índio. Salvar o índio era, no modo de entender do missionário, fazê-lo abandonar seus costumes “diabólicos” e impor-lhe o temor e a civilidade. Tal empresa se faria, acima de tudo, pela educação do corpo e dos sentidos. Nesse sentido, o regimento desenvolveu uma pedagogia religiosa destinada ao índio, baseada no princípio da repetição. O jesuíta sabia usar, e muito bem, dos artifícios retóricos do gesto e da fala. A oração, a missa e a doutrina cotidianas eram, por assim dizer, representadas para os índios como teatro pedagógico que lhes ensinava ao que deveriam aspirar. Assim, todos os dias, antes de ir trabalhar, os nativos deveriam assistir à oração, à missa e à doutrina. Acompanhe-se:

\begin{abstract}
Terminada a oração, que se diga uma Missa para que os índios possam ouvi-la antes de ir tomar seu serviço e antes ou depois da Missa que se Ihes faça a doutrina por um tempo curto, mais ou menos um quarto de hora, repartindo o diálogo de modo a ensiná-lo inteiro ao menos uma vez na semana, e à tarde tanto na semana como aos domingos, que se ensinem as orações da doutrina e que se tome um pouco de tempo para particular instrução daqueles que devem ser batizados, casar-se ou comungar de novo. (Para las Aldeias, \$10, ARSI, Bras. 2, fl. 146)
\end{abstract}

Gouveia certamente já havia tido notícias de que os padres costumavam castigar os índios nas aldeias e por isso recomendava não mais fazê-lo:

Havendo moços de escola os ensinarão por espaço de hora e meia, pela manhã como pela tarde, a ler e escrever e depois disso, cantar aos que parecerem que têm habilidade para isso, havendo quem o saiba fazer, mas não os castiguem por sua mão. (Para las Aldeias, §11, ARSI, Bras. 2, fl. 146)

As consequências dessas determinações do visitador atingiam fortemente os costumes indígenas que agora já estavam substituídos pelos cristãos. Observe-se como se dava aqui o controle das práticas dos índios por meio dos princípios contrarreformistas de disciplina sobre as práticas coletivas:

Quitem-se os maus costumes dos indios, como haver excessos nos vinhos e bailes de noite. E os bons se conservem, como dizer a salve aos sábados e as disciplinas e procissões da quaresma e, ao menos nas quatro principais festas, se houvesse Missa cantada para consolo dos índios e aumento da Cristandade. (Para las Aldeias, \$12, ARSI, Bras. 2, fl. 146. Grifos meus) 
Veja-se no excerto seguinte que, até mesmo em suas casas, os índios eram vigiados. Aqui o Geral em Roma, Pe. Claudio Aquaviva, ${ }^{7}$ acrescentava a determinação de não irem os jesuítas sozinhos àquelas casas: "As casas dos índios se visitarão uma vez por semana ou mais se for necessário. Que os nossos se vão acompanhados"8 (Para las Aldeias, $\S 14$, ARSI, Bras. 2, fl. 146. Grifos do original).

As determinações eram minuciosas e não havia como o índio escapar da pedagogia da vigilância aplicada pelos padres, pois os nativos eram obrigados à confissão. Como já havia a presença de um livro de registro, os índios estavam todos catalogados: não havia mais como se esconder. É interessante registrar também que os padres não podiam ser padrinhos dos índios. Confira-se:

\begin{abstract}
Trabalhem muito que se confessem os índios algumas vezes no ano e ao menos pela Páscoa estejam todos confessados e os que forem capazes possam comungar [...] E tenham particular conta com os catecúmenos, instruindo-os para o batismo, e quando batizarem alguns, inscreva-os em um livro que para isto haverá, e o dia e ano em que se batizaram. Os padrinhos não sejam da Compa, mas sim algum velho principal e virtuoso da mesma Aldeia. (Para las Aldeias, §15, ARSI, Bras. 2, fl. 146. Grifos meus)
\end{abstract}

Até no momento da morte o corpo do índio era controlado pelos padres. Era preciso garantir o "enterro cristão" a fim de se evitarem rituais condenáveis pelos inacianos. A vida do índio, agora cristão, passava a ser vigiada desde o nascimento até o enterro. Havia lugares privilegiados para alguns defuntos e, ainda mais, o índio não podia nem passar de uma aldeia a outra sem pedir licença:

Não enterrarão dentro das igrejas das Aldeias a nenhum índio sem li-
cença do Superior da casa ou Colégio a que estão anexas, salvo se fo-
rem alguns principais e suas mulheres, ou beneméritos da Igreja. Nem
consintam sem a mesma licença passar-se os índios de uma aldeia
para outra. (Para las Aldeias, \$18, ARSI, Bras. 2, fl. 147. Grifos meus)

$\mathrm{O}$ visitador estabeleceu que os superiores se aproximassem de alguns índios para falar-lhes dos mistérios divinos. Recorrendo à experiência, Gouveia estava convencido de que essa prática valia mais que a pregação na igreja:

Tenham momento os superiores de mandar chamar de quando em quando alguns índios, especialmente os velhos, e pratiquem com eles familiarmente de Deus, dos mistérios da vida de Cristo, criação do mundo e vida dos Santos, por se ter por experiência que disto se tira
7

De acordo com Assunção (2004), Pe. Cláudio Aquaviva foi eleito Geral da Ordem em primeiro escrutínio em 1581. Contava nessa época com apenas 37 anos de idade. Permaneceu no cargo até 1615. Com atenção voltada para o corpo de missionários, redigiu diversas exortações, instruções e cartas, salientando a importância do progresso da Companhia e a necessidade de continuar trilhando os caminhos da perfeição e da renovação do espírito. 8 Nos excertos do regimento, "tudo o que está riscado por baixo foi acrescentado em Roma pelo N. P. Geral" (ARSI, Bras. 2, fl. 148). 
De acordo com Castelnau-L'Estoile (2006), o regimento confirmava, portanto, o lugar da aldeia na província, definindo aos missionários os meios de realizar ali sua salvação e a dos índios. Esse documento de uso interno da Companhia levava também em consideração o mundo exterior - no caso, a sociedade colonial e os poderes políticos e religiosos -, pois a aldeia não era somente um espaço religioso, mas fundamentalmente um "espaço político", uma unidade administrativa onde viviam os índios "livres", e um "espaço econômico", o lugar onde se concentrava uma força de trabalho. Porém, apesar de evidentes tentativas conciliadoras, o regimento não conseguiu resolver a questão do lugar da aldeia na sociedade colonial, o que explica as dificuldades das aldeias jesuítas na década seguinte (CASTELNAU-L'ESTOILE, 2006). Como as dificuldades permaneceram, Aquaviva mandou visitar a província do Brasil novamente.

A Terceira Visita à Província do Brasil iniciou-se no ano de 1607. Como visitador, Roma determinou Pe. Manuel de Lima, professor da Universidade de Évora. Lima chegou ao Colégio de Pernambuco em dezembro de 1607, como consta do excerto abaixo copiado:

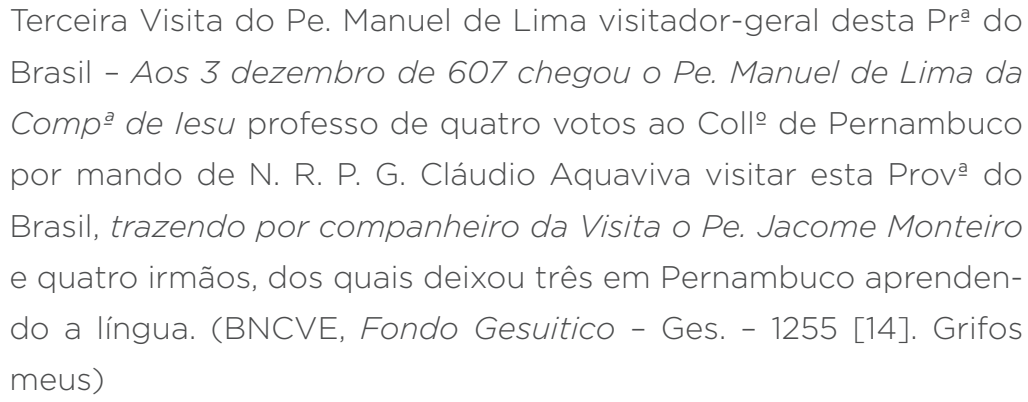

De acordo com Pompa (2003), a visita de Lima constituiu um complemento do regimento de Gouveia. Escritas em um momento de profunda renovação espiritual das missões, ${ }^{9}$ as regras de Lima iam todas na direção de fechar o espaço das aldeias para o mundo externo: por exemplo, isolavam os próprios missionários da população indígena, principalmente feminina (POMPA, 2003). Também se estabelecia, assim como já havia sido feito por Gouveia, a pedagogia da vigilância por meio de regras rígidas destinadas, sobretudo, aos próprios inacianos. Vamos, portanto, às determinações deixadas pelo visitador.

As primeiras determinações deixadas por Lima ao final da visita a questão da ocupação com coisas do "Espírito" e a crítica às ocupações “temporais” dos padres. Já no primeiro parágrafo, o visitador demonstrava preocupação com a "reformação do Espírito": "Com toda a diligência 
se executem as ordens de N. R. P. G. e em particular as que tratam da reformação do Espírito” (Para os Colégios, §1, BNCVE, Ges. 1255 [14]).

No excerto seguinte, o visitador insistia na questão da "formação" espiritual:

\begin{abstract}
Procure-se quando for possível que além do coadjutor espiritual, haja em cada Collo um padre de autoridade que possa ajudar ao superior no meneio do Collo e formação em o espírito. (Para os Colégios, §3, BNCVE, Ges. 1255 [14])
\end{abstract}

Reforçando ainda mais a "persistência do espiritual”, no quarto parágrafo havia uma advertência aos superiores: que buscassem a perfeição dos súditos e não se ocupassem das "coisas temporais":

\begin{abstract}
Como o bem espiritual dos súditos dependa tanto do espírito dos superiores, sério se adverte aos superiores que procurem mostrar que de verdade busquem a perfeição dos súditos que é o principal de seu ofício [...] e dar governação das coisas temporais ao ministro e procurador. (Para os Colégios, §4, BNCVE, Ges. 1255 [14]. Grifos meus)
\end{abstract}

Já o parágrafo $16^{10}$ ordenava que se aprendesse a língua da terra no próprio colégio, e não na aldeia, como defendia Gouveia. Repare-se que esse é um exemplo interessante de acirramento dos "modos de vigiar" e de tentar preservar a "vocação" dos padres por parte do centro da Ordem em Roma:

\footnotetext{
Os noviços, acabado o primeiro ano de provação, aprenderão a língua, para o que ordenamos haja no noviciado certo tempo em que [...] leiam, o que nos pareceu muito saudável para a conservação do Spiritu, o que facilmente perderiam metidos nas Aldeias, acabados os dois anos. (Para os Colégios, §16, BNCVE, Ges. 1255 [14]. Grifos meus)
}

Os fragmentos seguintes fundavam com detalhes a pedagogia da vigilância que o visitador organizou para as atividades dos inacianos. O parágrafo 17 insistia na mesma questão já apontada: "Não mandarão às Aldeias os que acabam o noviciado, senão depois que tiverem dois anos do Colégio”. O parágrafo 23 restringia o acesso a certos lugares das casas dos inacianos: "Na cozinha e outras oficinas e casa não entrem mais escravos ou índios que aqueles que para os tais ofícios forem destinados". O número 29 diz respeito ao andar desacompanhado: "De tal maneira se guarde a ordem de N. R. P. G. acerca de os nossos irem ou virem acompanhados das Aldeias”. O número 35 destacava a questão da instrução na "doutrina cristã" dos que viviam nas "roças" dos inacianos: "Façam

\section{0}

Os dois parágrafos que se referiam às festas (11 e 14) estão rabiscados, o que os tornou ilegíveis em grande parte no documento original, tornando possível apenas saber o assunto. Para mim, ficou claro que se tratou de censura. 
os superiores toda a diligência para que a gente que reside em nossas roças e fazendas seja bem instruída na doutrina cristã”. Já o número 36 ressaltava a disciplina e a vigilância que imperava nas casas jesuíticas. Veja-se que se estabelecia uma espécie de "solidariedade" no processo de vigilância, ou seja, um deveria tomar conta do outro, sempre: "Assim nos Colégios como nas Capitanias não virão abrir de noite a porta sem levarem consigo companheiro" (BNCVE, Ges. 1255 [14]. Grifos meus).

$\mathrm{O}$ excerto seguinte destaca as determinações referentes aos estudos. Acompanhe-se que as resoluções dirigidas aos estudantes deixavam claro que não se admitiam "abusos" e "exageros" nas atividades acadêmicas. O visitador também ordenou a respeito das propinas, gratificação que o doutorando das universidades europeias dava aos lentes ${ }^{11}$ pela sua intervenção e presença na solenidade do doutoramento, como se pode verificar a seguir:

1. Faça-se na sala dos estudos um lugar para hóspedes e religiosos e não se assentem nos assentos de mestres em artes [...].

4. Não se dê grau de mestres em artes senão àqueles que derem propinas, salvo quando algum por pobre houvesse deles com doacão dos mesmos mestres.

5. O grau de mestre em artes, havendo-se de dar (o que se não fará sem justa causa) antecipado aos mais; dê-se com solenidade na sala e com todas as cerimônias que se costumam usar.

6. Os nossos examinados sejam retos nos votos e não deem "cum maxima Laude”, senão aos que julgarem a merecem [...] assim com os nossos irmãos, como com os mais estudantes [...].

9. Guardem o estatuto geral das Universidades e não tirem o barrete aos cursistas. (Para os estudos, BNCVE, Ges. 1255 [14]. Grifos meus)

Ainda sobre as determinações respeitantes aos estudos, o documento explicitava a pedagogia da vigilância sobre as manifestações que se praticavam no espaço acadêmico. Para o visitador, nas apresentações não se deveriam vestir moços como mulheres, "mas como ninfas". Adiante, permitia-se a música, mas proibia-se a dança. Confiram-se as curiosas prescrições:

Eram assim chamados os professores de teologia moral, que também eram conhecidos como "lentes de casos de consciência". No começo do século XVII, havia no Brasi três professores que se encaixavam nesse perfil, cada qual nos três maiores colégios, da Bahia, do Rio de Janeiro e de Pernambuco. A visita de Pe. Manuel de Lima ordenava que houvesse pelos menos conferência semanal de casos de consciência, meia hora de cada vez (LEITE, VII, p. 180)
10. Não se façam tragédias que obriguem a fazer teatros fora dos estudos.

11. Nas obras que se fizerem não se vistam moços como mulheres, mas como ninfas, alevantada a roupa em um palmo do chão.

12. O ministro nos atos públicos e quais quer outros literários, não tem lugar particular, estando o Reitor no Collo.

13. Guarde-se a Visita do Pe. Cristóvão de Gouveia no que toca à solenidade de tirar os santos nas classes com música, à qual deve ser moderada. Mas não se admitam danças. 
No décimo parágrafo expunha-se a pedagogia da vigilância que deveria ser colocada em prática entre os próprios inacianos ao os obrigarem a devolver as chaves ao superior quando fossem à "portaria”. A presença do "outro" era também recomendada, assim como o foi por Gouveia. Assim, dizia: "Guardem a ordem que deixamos em geral de irem acompanhados à portaria depois das aves-marias, e levarem [...] as chaves ao superior" (Para as aldeias, §10, BNCVE, Ges. 1255 [14]. Grifos meus).

O fragmento seguinte é muito interessante porque explicitava a espécie de penitência aplicada nas aldeias:

\begin{abstract}
Os superiores das Aldeias podem e devem dar penitências aos que nela estão, como comer no chão e dizer a culpa [...] e executem o costume da Compa de dizerem entreano algumas vezes a culpa que faltou das regras. (Para as aldeias, \$12, BNCVE, Ges. 1255 [14]. Gifos meus)
\end{abstract}

O excerto abaixo reproduzido refere-se ao "falar com as índias" e novamente era invocada a presença do "outro" em uma espécie de “solidariedade na vigilância”. Confira-se:

Nenhum dos nossos que residem nas Aldeias fale com alguma india, ainda que seja nas igrejas, sem levar companheiro de casa. E o melhor será falar da varanda ou à porta, quando o negócio de si o pedisse. (Para as aldeias, \$13, BNCVE, Ges. 1255 [14]. Grifos meus)

No parágrafo transcrito adiante, o visitador insistia na restrição da presença da índia em "ministérios" que deveriam ser sempre ocupados pelos "moços":

Não se admita o costume que há em algumas Aldeias de trazerem água as indias moças para aguarem as igrejas quando as varrem, mas far-se-á este ministério por índios moços, o que também se devia guardar no trazer da água para o serviço de casa. (Para as aldeias, §16, BNCVE, Ges. 1255 [14]. Grifos meus)

O parágrafo seguinte voltava à questão da clausura que deveria haver nas casas e cubículos ocupados pelos inacianos: "Importa muito nas nossas Aldeias haja mais clausura do que há no que toca a nossas Casas e que as janelas dos cubículos tenham todas grades” (Para as aldeias, §17, BNCVE, Ges. 1255 [14]). 
As normas eram tão minuciosas que nem mesmo as roupas dos inacianos foram esquecidas pelo visitador: "A roupa dos nossos que residem nas Aldeias se não dê a lavar senão por ordem do Superior” (Para as aldeias, §18, BNCVE, Ges. 1255 [14]).

É interessante sopesar a vigilância que se estabeleceu para as vestes dos inacianos e perguntar: e quando o superior se ausentava, em que estado ficariam? É uma questão interessante para se pensar a respeito do cuidado (ou da falta de) com o corpo e com as vestes para o jesuíta.

A meu ver, a recomendação que aparecia no excerto seguinte expressava a preocupação referente à fuga dos índios das aldeias, motivo pelo qual não podiam levar consigo suas mulheres quando saíssem. De acordo com o texto, "Quando os índios forem servir os brancos não lhes consintam em nenhum modo levarem suas mulheres" (Para as aldeias, $\S 20$, BNCVE, Ges. 1255 [14]). O casamento dos índios também não escapava da "vigilância" disposta pelas determinações do visitador: "Não se casem índios forasteiros de outras Capitanias nas nossas Aldeias” (Para as aldeias, §21, BNCVE, Ges. 1255 [14]).

No parágrafo 22, o visitador recorria à “experiência” para recomendar aos inacianos que, "Quando os índios forem com suas famílias fazer alguma pescaria, não vão os nossos com eles, por evitar muitos inconvenientes que a experiência tem mostrado" (Para as aldeias, §22, BNCVE, Ges. 1255 [14]).

O fragmento seguinte falava da prática do "descimento" dos nativos do sertão para o litoral e novamente se evidenciava a preocupação com a fuga dos nativos das aldeias: "Não consintam que quando os nossos padres vão ao sertão buscar gentio, levem suas mulheres os índios" (Para as aldeias, §23, BNCVE, Ges. 1255 [14]. Grifos meus).

Ao final do texto do Visitador estavam os seguintes dizeres:

Manuel de Lima.

Esta Visita está aprovada pelo Pe. Geral.

Anto Mascarenhas. (BNCVE, Ges. 1255 [14])

\section{ALGUMAS CONSIDERAÇÕES}

Penso que a discussão a respeito da postura da Igreja da Contrarreforma com relação ao corpo e às práticas dos indivíduos nesse período é fundamental para se pensar o processo "civilizador" que o catolicismo pôs em cena nos séculos XVI e XVII por meio do que chamei de pedagogia da vigilância. Tal processo determinava o "modo de proceder" jesuítico, principalmente quando esse "modo" se encontrava com uma "humanidade" diferente, como foi o caso dos índios do Brasil.

Nesse sentido, defendo que a aldeia é um espaço fundamental para discutir a identidade da missão jesuítica no período sobre o qual 
me ocupei neste estudo. A meu ver, era justamente na aldeia que o padre inaciano ocupava um lugar de poder que certamente não alçaria em outros lugares. Vilipendiado e criticado por alguns superiores, o trabalho na aldeia aparecia como uma atividade na qual muitos inacianos enxergavam a "identidade" da missão e que defendiam, enquanto outros “rogavam com lágrimas” para serem retirados dali.

Penso, por conseguinte, que é ingênuo tentar constituir a história dos jesuítas no Brasil colonial se não se considera sua atividade na aldeia e não se leva em conta o "lugar de poder" que o jesuíta tinha aí. Digo isso porque a própria fonte jesuítica disponível nos arquivos pesquisados e que foi utilizada neste artigo quase não tratava do trabalho dos padres com os portugueses nas cidades ou com os alunos nos colégios. Por exemplo, era pela atividade dos jesuítas na aldeia que se definia parte do currículo que "formaria” os futuros padres. Na visão de boa parte dos clérigos da província do Brasil, sem as aldeias a missão jesuítica perderia seu significado em terras brasílicas. Como gostavam de dizer: "foi para isso que fomos enviados", para atuar na "conversão" dos “gentios”. Era essa a "paixão” que movia grande parte dos inacianos que por aqui estiveram nos séculos XVI e XVII. Ainda que Roma, com sua pedagogia da vigilância, não se cansasse de restringir o que se praticava ali e de ver na aldeia um "lugar perigoso" para a "vocação" inaciana, os jesuítas da província do Brasil a defendiam e viam na aldeia a "justificativa” da missão nessas terras.

Na minha percepção, portanto, a aldeia era, ao mesmo tempo, céu e inferno, lugar de “salvação" para alguns e lugar de “perdição” para outros. Indubitavelmente, contudo, era o principal espaço jesuítico na Colônia no período pesquisado.

É possível afirmar, por fim, que a "campanha pedagógica contrarreformista” colocou em cena a pedagogia da vigilância por meio de um rígido controle sobre as práticas dos indivíduos no período. No caso da América portuguesa, isso se fez fundamentalmente na aldeia. A intenção deste artigo foi, pois, aproximar o leitor desses fundamentos e da ambiência que provocou e tornou possíveis os embates desse tempo.

\section{REFERÊNCIAS}

ASSUNÇÃO, Paulo. Negócios jesuíticos: o cotidiano da administração dos bens divinos. São Paulo: Edusp, 2004.

CASTELNAU-L'ESTOILE, Charlotte. Operários de uma vinha estéril: os jesuítas e a conversão dos índios no Brasil - 1580-1620. Bauru: Edusc, 2006.

CERTEAU, Michel de. Fabula mística: la spiritualità religiosa tra il XVI e il XVII secolo. Bologna: Il Mulino, 1987.

GÉLIS, Jacques. O corpo, a Igreja e o sagrado. In: VIGARELLO, Georges (Dir.). História do corpo: da renascença às luzes. Petrópolis: Vozes, 2008. p. 19-130. 
HANSEN, João Adolfo. A sátira e o engenho: Gregório de Matos e a Bahia do século XVII. 2. ed. rev. São Paulo; Campinas: Ateliê; Editora da Unicamp, 2004.

KARNAL, Leandro. Teatro da fé: representação religiosa no Brasil e no México do século XVI. São Paulo: Hucitec, 1998.

LEITE, Serafim da Silva. História da Companhia de Jesus no Brasil. Rio de Janeiro: Instituto Nacional do Livro, 1938-1949. $10 \mathrm{v}$.

POMPA, Cristina. Religião como tradução: missionários, tupi e tapuia no Brasil colonial. Bauru: Edusc, 2003.

VIGARELLO, Georges. Introdução. In: VIGARELLO, Georges. História do corpo: da renascença às luzes. Petrópolis: Vozes, 2008. p. 15-18.

\section{ARQUIVOS E FONTES CONSULTADOS}

Archivum Romanum Societatis Iesu, Brasilia Epistolae, Roma.

Biblioteca Nazionale Centrale Vittorio Emanuelle, Fondo Gesuitico, Roma.

Monumenta Historica Societatis Iesu, Monumenta Brasiliae IV (1563-1568), Roma.

MARCOS ROBERTO DE FARIA

Professor da Universidade Federal de Alfenas - Unifal -, Alfenas,

Minas Gerais, Brasil

marcosfaria07@yahoo.com.br 